\title{
Schleiferia thermophila gen. nov., sp. nov., a slightly thermophilic bacterium of the phylum 'Bacteroidetes' and the proposal of Schleiferiaceae fam. nov.
}

\author{
Correspondence \\ Milton S. da Costa \\ milton@ci.uc.pt
}

\author{
Luciana Albuquerque, ${ }^{1}$ Fred A. Rainey, ${ }^{2}$ M. Fernanda Nobre ${ }^{3}$ \\ and Milton S. da Costa 3,4 \\ ${ }^{1}$ Center for Neuroscience and Cell Biology, University of Coimbra, 3004-517 Coimbra, Portugal \\ ${ }^{2}$ Department of Biological Sciences, Louisiana State University, Baton Rouge, LA 70803, USA \\ ${ }^{3}$ Department of Life Sciences, University of Coimbra, 3001-401 Coimbra, Portugal \\ ${ }^{4}$ BIOCANT, 3060-197 Cantanhede, Portugal
}

\begin{abstract}
A bacterial isolate, with an optimum growth temperature of about $50{ }^{\circ} \mathrm{C}$ and an optimum $\mathrm{pH}$ for growth between 7.5 and 8.5, was recovered from a hot spring in the Furnas area of the Island of São Miguel in the Azores. The novel isolate is orange-pigmented, forms non-motile, rod-shaped cells that stain Gram-negative, is strictly aerobic, oxidase-positive and catalase-negative. The major fatty acids of strain TU-20 are $16: 1 \omega 6 c, 17: 0$ iso $3-\mathrm{OH}$ and $15: 0$ iso. Menaquinone 6 is the major respiratory quinone. Based on $16 \mathrm{~S}$ rRNA gene sequence analysis, physiological and biochemical characteristics, we describe a novel species of a novel genus represented by strain TU-20 ${ }^{\top}$ (=DSM $21410^{\top}=$ LMG $24594^{\top}$ ) for which we propose the name Schleiferia thermophila gen nov., sp. nov. We also propose the family Schleiferiaceae fam. nov. to accommodate this new genus.
\end{abstract}

Most species of the phylum 'Bacteroidetes' have optimum growth temperatures that range from about 25 to $45^{\circ} \mathrm{C}$. Several organisms are psychrophilic with very low growth temperatures; these include Psychroserpens burtonensis, and members of the genera Gelidibacter and Maribacter (Bowman et al., 1997; Nedashkovskaya et al., 2004). However, within this phylum, thermophilic or slightly thermophilic species are very rare. Some of these organisms have slightly elevated growth temperatures of around 40$45{ }^{\circ} \mathrm{C}$, such as Pseudozobellia thermophila (Nedashkovskaya et al., 2009) and Lutaonella thermophilia (Arun et al., 2009), or are slightly thermophilic, namely Anaerophaga thermohalophila (Denger et al., 2002), with an optimum growth temperature around $50{ }^{\circ} \mathrm{C}$ but unable to grow at $60{ }^{\circ} \mathrm{C}$. The species of two other genera of the phylum 'Bacteroidetes' are thermophilic; these are Thermonema lapsum (Hudson et al., 1989) and Thermonema rossianum (Tenreiro et al., 1997), with optimum growth temperatures of about $60{ }^{\circ} \mathrm{C}$ and maximum growth temperatures around $65{ }^{\circ} \mathrm{C}$, and the two species of the genus Rhodothermus, namely Rhodothermus marinus and the recently described Rhodothermus profundi (Alfredsson et al., 1988; Nunes et al., 1995; Silva et al., 2000;

The GenBank/EMBL/DDBJ accession number for the 16S rRNA gene sequence of strain TU-20 ${ }^{\top}$ is HQ172900.

Two supplementary figures are available with the online version of this paper.
Marteinsson et al., 2010). The two species of the genus Rhodothermus have optimum growth temperatures of over $65{ }^{\circ} \mathrm{C}$ and maximum growth temperatures just below $80{ }^{\circ} \mathrm{C}$. The species of the genus Rhodothermus have the deepest branches of the phylum 'Bacteroidetes'.

We recently isolated several slightly thermophilic organisms from the Furnas area, such as Elioraea tepidiphila (Albuquerque et al., 2008), Tepidicella xavieri (França et al., 2006), Truepera radiovictrix (Albuquerque et al., 2005), Meiothermus timidus (Pires et al., 2005) and one undescribed slightly thermophilic organism with an optimum growth temperature around $50-55{ }^{\circ} \mathrm{C}$ and a maximum growth temperature of $60{ }^{\circ} \mathrm{C}$. Phylogenetic analysis of the $16 \mathrm{~S}$ rRNA gene sequence showed that this organism represents a distinct lineage within the phylum 'Bacteroidetes'. Based on phylogenetic, physiological and biochemical parameters, we are of the opinion that strain $\mathrm{TU}-20^{\mathrm{T}}$ represents a novel genus and species for which we propose the name Schleiferia thermophila gen. nov., sp. nov. We are also of the opinion that this organism represents a new family for which we propose the name Schleiferiaceae fam. nov.

Strain TU $-20^{\mathrm{T}}$ was isolated from a hot spring in the Furnas area of the Island of São Miguel in the Azores. Water samples were maintained without temperature control for 6 days, and then 10 to $100 \mathrm{ml}$ were filtered through 
membrane filters (Gelman type GN-6; pore size $0.45 \mu \mathrm{m}$; diameter $47 \mathrm{~mm}$ ). The filters were placed on the surface of solidified Thermus medium (Williams \& da Costa, 1992), the plates were wrapped in plastic to prevent evaporation and incubated at $50{ }^{\circ} \mathrm{C}$ for up to 4 days. Thermus medium contained the following components per litre of media: yeast extract (Difco), $1.0 \mathrm{~g}$; tryptone (Difco), $1.0 \mathrm{~g}$; agar (Difco), $20.0 \mathrm{~g} ; 100 \mathrm{ml} 10 \times$ concentrated macronutrients solution; $10 \mathrm{ml} 100 \times$ concentrated trace elements solution; and $10 \mathrm{ml} 0.17 \mathrm{mM} \mathrm{FeCl}{ }_{3} \cdot 6 \mathrm{H}_{2} \mathrm{O}$. The $10 \times$ concentrated macronutrients solution contained per litre: nitrilotriacetic acid, $1.0 \mathrm{~g} ; \mathrm{CaSO}_{4} \cdot 2 \mathrm{H}_{2} \mathrm{O}, 0.6 \mathrm{~g} ; \mathrm{MgSO}_{4} \cdot 7 \mathrm{H}_{2} \mathrm{O}, 1.0 \mathrm{~g} ; \mathrm{NaCl}$, $0.08 \mathrm{~g} ; \mathrm{KNO}_{3}, 1.03 \mathrm{~g} ; \mathrm{NaNO}_{3}, 6.89 \mathrm{~g}$; and $\mathrm{NaHPO}_{4}, 1.11 \mathrm{~g}$. The $100 \times$ concentrated trace elements solution contained per litre: $\mathrm{MnSO}_{4} \cdot \mathrm{H}_{2} \mathrm{O}, 0.22 \mathrm{~g} ; \mathrm{ZnSO}_{4} \cdot 7 \mathrm{H}_{2} \mathrm{O}, 0.05 \mathrm{~g}$; $\mathrm{H}_{3} \mathrm{BO}_{3}, 0.05 \mathrm{~g} ; \mathrm{CuSO}_{4} \cdot 5 \mathrm{H}_{2} \mathrm{O}, 0.0025 \mathrm{~g} ; \mathrm{Na}_{2} \mathrm{MoO}_{4} \cdot 2 \mathrm{H}_{2} \mathrm{O}$, $0.0025 \mathrm{~g}$; and $\mathrm{CoCl}_{2} \cdot 6 \mathrm{H}_{2} \mathrm{O}, 0.0046 \mathrm{~g}$. Cultures were purified by subculturing and the isolates stored at $-70{ }^{\circ} \mathrm{C}$ in Thermus medium with $15 \%$ (w/v) glycerol. Culture in Degryse medium 162 (Degryse et al., 1978), containing $0.25 \%$ yeast extract and $0.25 \%$ tryptone, was later adopted because this medium resulted in higher growth yields. Degryse medium contained the following components per litre of media: yeast extract (Difco), $2.5 \mathrm{~g}$; tryptone (Difco), $2.5 \mathrm{~g}$; agar (Difco), $20.0 \mathrm{~g} ; 100 \mathrm{ml} 10 \times$ concentrated macronutrients solution; $5 \mathrm{ml} 100 \times$ concentrated trace elements solution; $0.5 \mathrm{ml}$ $0.01 \mathrm{M} \mathrm{C}_{6} \mathrm{H}_{5} \mathrm{O}_{7} \mathrm{Fe} .5 \mathrm{H}_{2} \mathrm{O}, 10 \mathrm{ml} 0.2 \mathrm{M} \mathrm{KH}_{2} \mathrm{PO}_{4}$ and $15 \mathrm{ml}$ $0.2 \mathrm{M} \mathrm{Na}_{2} \mathrm{HPO}_{4} \cdot 12 \mathrm{H}_{2} \mathrm{O}$. The $10 \times$ concentrated macronutrients solution contained per litre: nitrilotriacetic acid, $1.0 \mathrm{~g} ; \mathrm{CaSO}_{4} \cdot 2 \mathrm{H}_{2} \mathrm{O}, 0.4 \mathrm{~g}$; and $\mathrm{MgSO}_{4} \cdot 7 \mathrm{H}_{2} \mathrm{O}, 2.0$ g. The $100 \times$ concentrated trace elements solution contained per litre: $\mathrm{MnSO}_{4} \cdot \mathrm{H}_{2} \mathrm{O}, 0.22 \mathrm{~g} ; \mathrm{ZnSO}_{4} \cdot 7 \mathrm{H}_{2} \mathrm{O}, 0.05 \mathrm{~g} ; \mathrm{H}_{3} \mathrm{BO}_{3}$, $0.05 \mathrm{~g} ; \mathrm{CuSO}_{4} \cdot 5 \mathrm{H}_{2} \mathrm{O}, 0.0025 \mathrm{~g} ; \mathrm{Na}_{2} \mathrm{MoO}_{4} \cdot 2 \mathrm{H}_{2} \mathrm{O}, 0.0025 \mathrm{~g}$; $\mathrm{CoCl}_{2} \cdot 6 \mathrm{H}_{2} \mathrm{O}, 0.0046 \mathrm{~g}$.

The type strain of Fluviicola taffensis (DSM $16823^{\mathrm{T}}$ ) was used for comparative purposes.

Unless otherwise stated, all biochemical and tolerance tests were performed as described by Smibert \& Krieg (1981) and Albuquerque et al. (2010) in Degryse medium 162 or Degryse agar 162 (Degryse et al., 1978) at $50{ }^{\circ} \mathrm{C}$ for up to 6 days. Cell morphology and motility were examined by phase-contrast microscopy during the exponential growth phase. Gliding motility was examined as described by Bernardet et al. (2002). The growth temperature range of the strains was examined in $5{ }^{\circ} \mathrm{C}$ increments between 25 and $65{ }^{\circ} \mathrm{C}$ by measuring the turbidity $(610 \mathrm{~nm})$ of cultures incubated in $300 \mathrm{ml}$ metal-capped Erlenmeyer flasks containing $100 \mathrm{ml}$ of medium in a rotary water-bath shaker at 150 r.p.m. The $\mathrm{pH}$ range for growth was examined in liquid medium by using $50 \mathrm{mM}$ MES, HEPES, TAPS or CAPSO over a $\mathrm{pH}$ range from 6.0 to 10.0 in a rotary water-bath shaker. The salt tolerance of the organisms was determined in liquid medium, with $\mathrm{NaCl}$ ranging between 0.0 and $4.0 \%$. Catalase, oxidase and DNase activities were examined as described by Smibert \& Krieg (1981) and Albuquerque et al. (2010). Additional enzymic activities were obtained using the API ZYM system (bioMérieux) at $50{ }^{\circ} \mathrm{C}$. Anaerobic growth was assessed in cultures in the same medium, containing $\mathrm{KNO}_{3}\left(1.0 \mathrm{~g} \mathrm{l}^{-1}\right)$, incubated in anaerobic chambers (GENbox anaer; bioMérieux). Single-carbon-source assimilation tests were performed in a medium composed of Degryse basal salts (Degryse et al., 1978) to which filtersterilized ammonium sulfate $\left(0.5 \mathrm{~g} \mathrm{l}^{-1}\right)$, yeast extract $\left(0.2 \mathrm{~g} \mathrm{l}^{-1}\right)$, vitamin B12 $\left(40 \mu \mathrm{g}^{-1}\right)$ and the carbon source $\left(2.0 \mathrm{~g} \mathrm{l}^{-1}\right)$ were added. Growth of the strains on single carbon sources was examined by measuring the turbidity of cultures incubated at $50{ }^{\circ} \mathrm{C}$ in $20 \mathrm{ml}$ screw-capped tubes containing $10 \mathrm{ml}$ medium for up to 6 days. Acid production from carbohydrates was determined by using the API $50 \mathrm{CH}$ system (bioMérieux) according to the manufacturer's instructions, using API $50 \mathrm{CHB} / \mathrm{E}$ medium. Results were recorded after $48 \mathrm{~h}$ and 6 days of incubation at $50{ }^{\circ} \mathrm{C}$.

Metabolic products were determined by growing the cultures in Degryse liquid medium overnight. The cultures were washed by centrifugation and incubated at $50{ }^{\circ} \mathrm{C}$ in $50 \mathrm{mM}$ phosphate buffer, $\mathrm{pH} 7.5$, containing glucose (11.1 mmol) or fructose $(11.1 \mathrm{mmol})$ at a turbidity of 7-8 (OD $610 \mathrm{~nm}$ ) for $24 \mathrm{~h}$ with periodic samplings and centrifuged. The samples were analysed using standard proton-nuclear magnetic resonance $\left({ }^{1} \mathrm{H}-\mathrm{NMR}\right)$ on a Bruker AMX300 spectrometer (Antunes et al., 2002).

Chemolithoorganotrophic growth on sodium thiosulfate was assessed under aerobic conditions at the optimum growth temperature in DSMZ medium 27 (http://www. dsmz.de/microorganisms/medium/pdf/DSMZ_Medium27. pdf) lacking ethanol and sulphate, and containing yeast extract $\left(1.0 \mathrm{~g} \mathrm{l}^{-1}\right)$, succinate $\left(1.0 \mathrm{~g} \mathrm{l}^{-1}\right)$ and acetate $(0.5 \mathrm{~g}$ $\left.1^{-1}\right)$. Filter-sterilized sodium thiosulfate was added to the medium at concentrations that varied between 0.5 and $5.0 \mathrm{~g} \mathrm{l}^{-1}$. At appropriate intervals, the turbidity of the cultures was determined and the cells were harvested and centrifuged. The levels of thiosulfate and sulfate in the supernatants were determined using the methods described by Westley (1987) and Sörbo (1987), respectively.

The cultures for polar lipid analysis were grown in 1 litre Erlenmeyer flasks containing $250 \mathrm{ml}$ medium at $50{ }^{\circ} \mathrm{C}$ in a rotary water-bath shaker until the late exponential phase of growth. Harvesting of the cultures and extraction of lipids was as described by da Costa et al. (2006). Individual polar lipids were separated by two-dimensional thin-layer chromatography and visualized as described previously (da Costa et al., 2006). Lipoquinones were extracted from freeze-dried cells and purified by thin-layer chromatography as described previously (da Costa et al., 2006). The lipoquinones were separated by high performance liquid chromatography with a Gilson HPLC by using a reversephase Hichrom $5 \mathrm{C} 18$ column and methanol/heptane $(10: 2, \mathrm{v} / \mathrm{v})$ as the mobile phase and were detected at $269 \mathrm{~nm}$. Cultures for fatty acid analysis were grown on solidified Degryse medium 162 in sealed plastic bags submerged in a water bath at $50{ }^{\circ} \mathrm{C}$ for $48 \mathrm{~h}$. Fatty acid 
methyl esters (FAMEs) were obtained from fresh wet biomass and separated, identified and quantified with the standard MIS Library Generation Software (Microbial ID) as described previously (da Costa et al., 2006).

DNA for the determination of $\mathrm{G}+\mathrm{C}$ content was isolated as described by Nielsen et al. (1995). The G $+\mathrm{C}$ content of DNA was determined by high-performance liquid chromatography as described by Mesbah et al. (1989).

A 16S rRNA gene sequence comprising 1499 nt was determined for strain $\mathrm{TU}-20^{\mathrm{T}}$ as previously described (Rainey et al., 1996). The $16 \mathrm{~S}$ rRNA gene was amplified in a number of fragments using the primer combinations 27f-519r, 27f1385r, 357f-1525r and 536f-1525r (Rainey et al., 1996). The taxonomic affiliation of strain $\mathrm{TU}-20^{\mathrm{T}}$, including the designation of its closest relatives based on the $16 \mathrm{~S}$ rRNA gene sequence, was determined using the EzTaxon facility (Chun et al., 2007).

Strain TU $-20^{\mathrm{T}}$ formed very short, Gram-stain-negative, rod-shaped cells $(0.5$ to $0.7 \mu \mathrm{m}$ in width and 0.5 to $1.5 \mu \mathrm{m}$ in length) without flagella and without visible gliding motility. Colonies were orange-pigmented on Degryse medium 162. The organism had an optimum growth temperature of about $50{ }^{\circ} \mathrm{C}$ and did not grow at 25 or $62.5^{\circ} \mathrm{C}$. This organism was oxidase-positive and catalasenegative and hydrolysed hippurate, starch, gelatin and casein. Aesculin, arbutin and xylan were not hydrolysed. Other enzyme activities are listed in the species description.
Small amounts of yeast extract $\left(0.2 \mathrm{~g} \mathrm{l}^{-1}\right)$ and vitamin B12 $\left(40 \mu \mathrm{g} \mathrm{l}^{-1}\right)$ were added to the minimal medium to assess assimilation of single carbon sources. The organism produced acid from several carbohydrates, leading us to determine the acids produced. However, only very low levels of succinate were detected. Nitrate was reduced to nitrogen, but anaerobic growth with nitrate as electron acceptor was not observed (Table 1). Thiosulfate was completely oxidized to sulphate in media containing 0.5 , 1.0 and $2.0 \mathrm{~g}$ thiosulfate $1^{-1}$ but there was no measurable increase in biomass.

The polar lipid pattern produced by thin-layer chromatography revealed the presence of one aminophospholipid, two aminolipids and three unidentified lipids. We also examined the polar lipids of $F$. taffensis, where we encountered one phospholipid, one aminophospholipid, one aminolipid and two unidentified lipids (Supplementary Fig S1, available in IJSEM Online), but only two lipids, an aminophospholipid and an aminolipid seem to be shared by both organisms. Moreover, strain TU- $20^{\mathrm{T}}$ possesses a major aminophospholipid which is not found in F. taffensis. The major respiratory lipoquinone was menaquinone 6 , as in all members of the families Cryomorphaceae and Flavobacteriaceae examined. The fatty acid composition of strain $\mathrm{TU}-20^{\mathrm{T}}$ was dominated by $16: 1 \omega 6 c, 17: 0$ iso $3-\mathrm{OH}$ and $15: 0$ iso (Table 2). However, many other organisms within the phylum 'Bacteroidetes' have large amounts of branched-chain fatty acids and 2- and 3-OH fatty acids.

Table 1. Differential characteristics of strain $\mathrm{TU}-20^{\top}$ and the type species of the genera Owenweeksia, Cryomorpha and Fluviicola of the family Cryomorphaceae

-, Negative; + , positive; $(+)$, weakly positive.

\begin{tabular}{|c|c|c|c|c|}
\hline Characteristics & Strain TU-20 ${ }^{\mathrm{T}}$ & Owenweeksia $^{a_{*}}$ & Cryomorphab & Fluviicola ${ }^{c}$ \\
\hline Gliding motility & - & + & - & + \\
\hline Habitat & Freshwater & Marine & Marine & Freshwater \\
\hline Growth temperature range $\left({ }^{\circ} \mathrm{C}\right)$ & $30-60$ & $4-37$ & $-2-25$ & $4-25$ \\
\hline Optimum growth temperature $\left({ }^{\circ} \mathrm{C}\right)$ & 50 & $25-33$ & 15 & 20 \\
\hline \multicolumn{5}{|l|}{ Growth on: } \\
\hline $0 \% \mathrm{NaCl}$ & + & - & - & + \\
\hline $3 \% \mathrm{NaCl}$ & + & + & + & - \\
\hline $6 \% \mathrm{NaCl}$ & - & + & + & - \\
\hline Utilization of glucose & + & - & - & - \\
\hline Acid production from glucose & + & - & - & - \\
\hline Nitrate reduction & + & - & - & - \\
\hline \multicolumn{5}{|l|}{ Presence of: } \\
\hline Oxidase & + & + & - & - \\
\hline Catalase & - & + & + & + \\
\hline \multicolumn{5}{|l|}{ Hydrolysis of: } \\
\hline DNA & + & - & - & + \\
\hline Gelatin & + & + & - & $(+)$ \\
\hline Presence of $17: 0$ iso $3-\mathrm{OH}$ & + & + & - & + \\
\hline DNA G $+\mathrm{C}$ content $(\mathrm{mol} \%)$ & 42.8 & 39.6 & $36-37$ & 37.2 \\
\hline
\end{tabular}

${ }^{\star}$ Data from: $a$, Lau et al. (2005); b, Bowman et al. (2003); c, O’Sullivan et al. (2005). 
Table 2. Mean fatty acid composition of strain $\mathrm{TU}-20^{\top}$ grown at $50{ }^{\circ} \mathrm{C}$ and $35{ }^{\circ} \mathrm{C}$, and Fluviicola taffensis grown at $25^{\circ} \mathrm{C}$

Data are percentages of total fatty acids and are presented as the mean \pm standard deviation of two to four analyses. tr, Trace $(<0.2 \%)$; - , not detected.

\begin{tabular}{|c|c|c|c|}
\hline \multirow[t]{2}{*}{ Fatty acid } & \multicolumn{2}{|c|}{ TU-20 ${ }^{\mathrm{T}}$} & \multirow{2}{*}{$\begin{array}{c}\begin{array}{c}\text { Fluviicola } \\
\text { taffensis }\end{array} \\
25{ }^{\circ} \mathrm{C}\end{array}$} \\
\hline & $50{ }^{\circ} \mathrm{C}$ & $35{ }^{\circ} \mathrm{C}$ & \\
\hline $11: 0$ iso & $0.7 \pm 0.1$ & $0.8 \pm 0.1$ & - \\
\hline $13: 0$ iso & $1.8 \pm 0.1$ & $1.8 \pm 0.2$ & $\operatorname{tr}$ \\
\hline $13: 0$ & - & $\operatorname{tr}$ & $0.5 \pm 0.0$ \\
\hline Unknown $\mathrm{ECL}^{*} 13.565$ & $0.5 \pm 0.2$ & $0.5 \pm 0.0$ & $\operatorname{tr}$ \\
\hline $14: 0$ & - & $\operatorname{tr}$ & $2.0 \pm 0.0$ \\
\hline $15: 1$ iso $G$ & $3.1 \pm 0.1$ & $14.7 \pm 0.7$ & $17.9 \pm 0.5$ \\
\hline $15: 0$ iso & $18.8 \pm 1.2$ & $34.8 \pm 2.0$ & $36.9 \pm 0.5$ \\
\hline $15: 0$ anteiso & $\operatorname{tr}$ & $\operatorname{tr}$ & $0.9 \pm 0.1$ \\
\hline Unknown ECL 14.815 & - & $1.6 \pm 0.1$ & $3.3 \pm 0.0$ \\
\hline $15: 0$ & $6.4 \pm 0.1$ & $6.5 \pm 0.8$ & $6.8 \pm 0.4$ \\
\hline $16: 1 \omega 6 c$ & $23.2 \pm 1.5$ & $9.0 \pm 1.4$ & $12.3 \pm 0.5$ \\
\hline $16: 0$ & $0.7 \pm 0.1$ & $0.6 \pm 0.1$ & $0.7 \pm 0.0$ \\
\hline $15: 0$ iso $3-\mathrm{OH}$ & $2.6 \pm 0.1$ & $4.0 \pm 0.4$ & $\operatorname{tr}$ \\
\hline $15: 02-\mathrm{OH}$ & $8.4 \pm 1.3$ & $1.8 \pm 0.2$ & $3.3 \pm 0.1$ \\
\hline $15: 03-\mathrm{OH}$ & $0.8 \pm 0.1$ & $1.0 \pm 0.1$ & $1.0 \pm 0.1$ \\
\hline Unknown ECL 16.580 & $0.8 \pm 0.2$ & $0.8 \pm 0.2$ & $1.0 \pm 0.1$ \\
\hline $17: 1 \omega 6 c$ & $1.1 \pm 0.1$ & $\operatorname{tr}$ & - \\
\hline $16: 03-\mathrm{OH}$ & $0.5 \pm 0.0$ & $\operatorname{tr}$ & $2.3 \pm 0.1$ \\
\hline $17: 0$ iso $2-\mathrm{OH}$ & $0.7 \pm 0.0$ & $\operatorname{tr}$ & - \\
\hline $17: 0$ iso $3-\mathrm{OH}$ & $22.3 \pm 1.3$ & $17.5 \pm 0.3$ & $8.4 \pm 0.2$ \\
\hline $17: 02-\mathrm{OH}$ & $0.7 \pm 0.0$ & - & - \\
\hline $17: 03-\mathrm{OH}$ & $5.5 \pm 0.1$ & $1.5 \pm 0.1$ & $\operatorname{tr}$ \\
\hline
\end{tabular}

${ }^{\star} \mathrm{ECL}$, equivalent chain-length.

Phylogenetic analyses using a dataset that included the $16 \mathrm{~S}$ rRNA gene sequence of the type strain of all genera of the phylum 'Bacteroidetes' showed strain TU- $20^{\mathrm{T}}$ to represent a distinct family-level line of descent. The TU $-20^{\mathrm{T}}$ lineage falls outside of all of the described and proposed (Bergey's Taxonomic Outline; http://www.bergeys.org/outlines/bergeys vol_4_outline_linked.pdf) families of the phylum 'Bacteroidetes' (Supplementary Fig S2). The highest sequence similarity was approximately $86 \%$ with the species of the genera Owenweeksia, Cryomorpha, Lishizhenia, Brumimicrobium, Wandonia, Fluviicola and Crocinitomix (Bowman et al., 2003; Lau et al., 2005, 2006; Lee et al., 2010; O'Sullivan et al., 2005), which have been classified as members of the family Cryomorphaceae (Bowman et al., 2003). The next closest relatives, based on pairwise similarity values $(82$ $83 \%)$ and phylogenetic position, are the species of the family Flavobacteriaceae (Fig. 1 and Supplementary Fig. S2). Fig 1 and Supplementary Fig. S2 clearly demonstrate the lack of relationship of strain TU- $20^{\mathrm{T}}$ with any of the lineages within the phylum 'Bacteroidetes' and support its description as a novel taxon at the family level. On the basis of the results, we propose that strain $\mathrm{TU}-20^{\mathrm{T}}$ represents a novel species of a novel genus for which we recommend the name Schleiferia thermophila gen. nov., sp. nov. We also propose that this organism represents a new family of the phylum 'Bacteroidetes' for which we recommend the name Schleiferiaceae fam. nov.

\section{Description of Schleiferia gen. nov.}

Schleiferia (Schlei.fe'ri.a. N.L. fem. n. Schleiferia named in honour of the German microbiologist Karl-Heinz Schleifer).

Forms non-motile, rod-shaped cells that stain Gram-negative. Endospores are not formed. Strictly aerobic, oxidase-positive and catalase-negative. Slightly thermophilic. Major fatty acids are $16: 1 \omega 6 c, 17: 0$ iso $3-\mathrm{OH}$ and $15: 0$ iso; menaquinone 6 is the major respiratory quinone. The $\mathrm{G}+\mathrm{C}$ content of the DNA of the type species is $42.8 \mathrm{~mol} \%$. The type species is Schleiferia thermophila.

\section{Description of Schleiferia thermophila sp. nov.}

Schleiferia thermophila (ther.mo'phi.la. Gr. adj. thermos hot; Gr. adj. philos loving; N.L. fem. adj. thermophila heatloving).

In addition to the characteristics reported for the genus, forms very short rod-shaped cells, 0.5 to $1.5 \mu \mathrm{m}$ in length and 0.5 to $0.7 \mu \mathrm{m}$ in width, without motility. Colonies on Degryse medium 162 are orange-pigmented and irregular. Growth occurs between 30 and $60{ }^{\circ} \mathrm{C}$. The optimum growth temperature is about $50{ }^{\circ} \mathrm{C}$; growth does not occur at 25 or $62.5^{\circ} \mathrm{C}$. The optimum $\mathrm{pH}$ for growth is between 7.5 and 8.5; growth does not occur at $\mathrm{pH} 6.0$ or $\mathrm{pH} 10.0$. Grows in media with up to $3 \%$ salt; however, optimum growth occurs in medium without added $\mathrm{NaCl}$. Yeast extract and vitamin B12 are required for growth. Nitrate is reduced to nitrogen. The polar lipid profile is composed of one aminophospholipid, two aminolipids and three unidentified lipids. Gelatin, casein and hippurate are degraded; starch, aesculin, arbutin and xylan are not degraded. DNase-positive. Alkaline phosphatase, esterase (C4), esterase lipase (C8), leucine arylamidase, valine arylamidase, cystine arylamidase, trypsin, acid phosphatase and naphthol-AS-BI-phosphohydrolase are positive in the API ZYM system; other activities are negative. Glucose, fructose, galactose, mannose, D-arabinose, sucrose, maltose, lactose, trehalose, acetate, succinate, fumarate, aspartate, glutamate, proline, L-glutamine, L-arginine, Lornithine and threonine are assimilated. L-Rhamnose, Lfucose, L-sorbose, D-ribose, D-xylose, L-arabinose, cellobiose, raffinose, melezitose, glycerol, ribitol, xylitol, sorbitol, mannitol, myo-inositol, erythritol, D-arabitol, L-arabitol, $\alpha$-ketoglutarate, pyruvate, malate, citrate, benzoate, formate, D-gluconate, D-glucuronate, L-alanine, L-asparagine, glycine, L-histidine, L-lysine, L-serine, valine, L-phenylalanine, Lleucine, L-isoleucine and methionine are not assimilated. Acid is produced from the following carbohydrates using API $50 \mathrm{CH}$ : D-arabinose, L-arabinose, D-ribose, D-xylose, L-xylose, D-galactose, D-glucose, D-fructose, D-mannose, L-sorbose, $\mathrm{N}$ acetylglucosamine, maltose, starch, turanose, D-lyxose, 


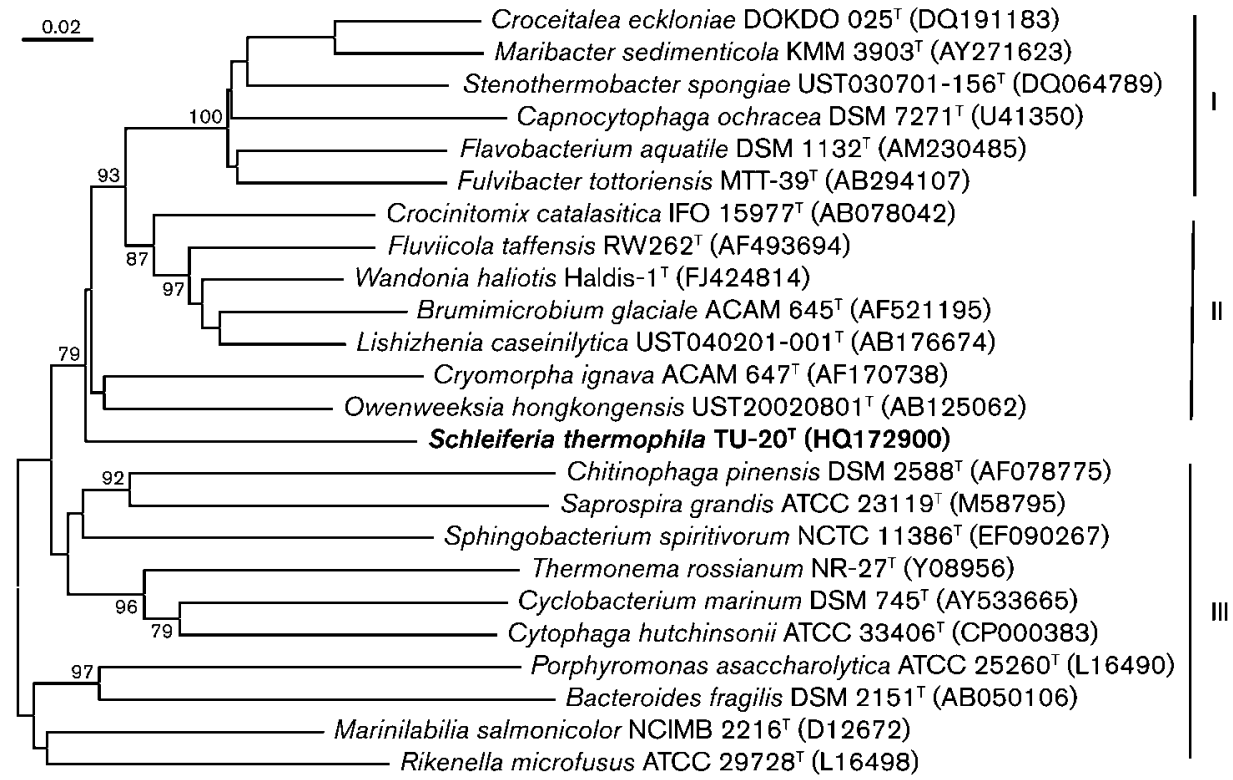

Fig. 1. 16S rRNA gene sequence based phylogeny demonstrating the relationship of strain $\mathrm{TU}-20^{\top}$ with taxa of the phylum 'Bacteroidetes'. The tree was reconstructed by using the neighbour-joining method using the MEGA 4.0 software package. Cluster I contains representatives of the family Flavobacteriaceae, cluster II the type species of the genera currently assigned to the family Cryomorphaceae (Bergey's Taxonomic Outline; http://www.bergeys.org/outlines/bergeys_vol_4_outline_linked.pdf), and cluster III comprises representatives of other family-level lineages within the phylum. Bar, 2 substitutions per 100 nucleotides. Numbers at branching points represent bootstrap values (based on 1000 resamplings).

D-tagatose and potassium 5-ketogluconate. The DNA of the type strain has a $\mathrm{G}+\mathrm{C}$ content of $42.8 \pm 0.1 \mathrm{~mol} \%$ (HPLC method).

The type strain, TU-20 ${ }^{\mathrm{T}}\left(=\mathrm{DSM} 21410^{\mathrm{T}}=\mathrm{LMG} 24594^{\mathrm{T}}\right)$, was isolated from a hot spring at Furnas on the Island of São Miguel in the Azores.

\section{Description of Schleiferiaceae fam. nov.}

Schleiferiaceae (Schlei.fe.ri.a.ce' a.e. N.L. fem. n. Schleiferia type genus of the family; suff. -aceae ending to denote a family; N.L. fem. pl. n. Schleiferiaceae family of the genus Schleiferia).

Cells are Gram-negative and very short rod-shaped. Endospores are not formed. Slightly thermophilic. Major respiratory quinone is menaquinone $6(\mathrm{MK}-6)$. The family Schleiferiaceae belongs to the Phylum 'Bacteroidetes'. The type genus of this family is Schleiferia.

\section{Acknowledgements}

We are indebted to Jean P. Euzéby (École National Vétérinaire, Toulouse, France) for the etymology of the novel organism's name. We would also like to thank Susanne Verbarg (Deutsche Sammlung von Mikroorganismen und Zellkulturen, Braunschweig, Germany) for the analysis of gliding motility and Pedro Lamosa (Centro de Ressonância Magnética António Xavier, Instituto de Tecnologia Química e Biológica, Oeiras, Portugal) for the NMR analysis.

\section{References}

Albuquerque, L., Simões, C., Nobre, M. F., Pino, N. M., Battista, J. R., Silva, M. T., Rainey, F. A. \& da Costa, M. S. (2005). Truepera radiovictrix gen. nov., sp. nov., a new radiation resistant species and the proposal of Trueperaceae fam. nov. FEMS Microbiol Lett 247, 161-169.

Albuquerque, L., Rainey, F. A., Nobre, M. F. \& da Costa, M. S. (2008). Elioraea tepidiphila gen. nov., sp. nov., a slightly thermophilic member of the Alphaproteobacteria. Int J Syst Evol Microbiol 58, 773-778.

Albuquerque, L., Rainey, F. A., Nobre, M. F. \& da Costa, M. S. (2010). Meiothermus granaticius sp. nov., a new slightly thermophilic redpigmented species from the Azores. Syst Appl Microbiol 33, 243-246.

Alfredsson, G. A., Kristjansson, J. K., Hjörleifsdottir, S. H. \& Stetter, K. O. (1988). Rhodothermus marinus, gen. nov., sp. nov., a thermophilic, halophilic bacterium from submarine hot springs in Iceland. J Gen Microbiol 134, 299-306.

Antunes, A., Rainey, F. A., Nobre, M. F., Schumann, P., Ferreira, A. M., Ramos, A., Santos, H. \& da Costa, M. S. (2002). Leuconostoc ficulneum sp. nov., a novel lactic acid bacterium isolated from a ripe fig, and reclassification of Lactobacillus fructosus as Leuconostoc fructosum comb. nov. Int J Syst Evol Microbiol 52, 647-655.

Arun, A. B., Chen, W.-M., Lai, W.-A., Chou, J.-H., Shen, F.-T., Rekha, P. D. \& Young, C.-C. (2009). Lutaonella thermophila gen. nov., sp. nov., a moderately thermophilic member of the family Flavobacteriaceae isolated from a coastal hot spring. Int J Syst Evol Microbiol 59, 2069-2073.

Bernardet, J.-F., Nakagawa, Y., Holmes, B. \& Subcommittee on the taxonomy of Flavobacterium and Cytophaga-like bacteria of the International Committee on Systematics of Prokaryotes (2002). 
Proposed minimal standards for describing new taxa of the family Flavobacteriaceae and emended description of the family. Int J Syst Evol Microbiol 52, 1049-1070.

Bowman, J. P., McCammon, S. A., Brown, J. L., Nichols, P. D. \& McMeekin, T. A. (1997). Psychroserpens burtonensis gen. nov., sp. nov., and Gelidibacter algens gen. nov., sp. nov., psychrophilic bacteria isolated from antarctic lacustrine and sea ice habitats. Int $J$ Syst Bacteriol 47, 670-677.

Bowman, J. P., Nichols, C. M. \& Gibson, J. A. E. (2003). Algoriphagus ratkowskyi gen. nov., sp. nov., Brumimicrobium glaciale gen. nov., sp. nov., Cryomorpha ignava gen. nov., sp. nov. and Crocinitomix catalasitica gen. nov., sp. nov., novel flavobacteria isolated from various polar habitats. Int J Syst Bacteriol 53, 1343-1355.

Chun, J., Lee, J.-H., Jung, Y., Kim, M., Kim, S., Kim, B. K. \& Lim, Y. W. (2007). EzTaxon: a web-based tool for the identification of prokaryotes based on $16 \mathrm{~S}$ ribosomal RNA gene sequences. Int J Syst Evol Microbiol 57, 2259-2261.

da Costa, M. S., Nobre, M. F. \& Wait, R. (2006). Analysis of lipids from extremophilic bacteria. In Extremophiles, Methods in Microbiology, vol. 35, pp. 127-159. Edited by F.A. Rainey \& A Oren. London: Academic Press.

Degryse, E., Glansdorff, N. \& Piérard, A. (1978). A comparative analysis of extreme thermophilic bacteria belonging to the genus Thermus. Arch Microbiol 117, 189-196.

Denger, K., Warthmann, R., Ludwig, W. \& Schink, B. (2002). Anaerophaga thermohalophila gen. nov., sp. nov., a moderately thermohalophilic, strictly anaerobic fermentative bacterium. Int $J$ Syst Evol Microbiol 52, 173-178.

França, L., Rainey, F. A., Nobre, M. F. \& da Costa, M. S. (2006). Tepidicella xavieri gen. nov., sp. nov., a betaproteobacterium isolated from a hot spring runoff. Int J Syst Evol Microbiol 56, 907-912.

Hudson, J. A., Schofield, K. M., Morgan, H. W. \& Daniel, R. M. (1989). Thermonema lapsum gen. nov., sp. nov., a thermophilic gliding bacterium. Int J Syst Bacteriol 39, 485-487.

Lau, K. W. K., Ng, C. Y. M., Ren, J., Lau, S. C. L., Qian, P.-Y., Wong, P.-K., Lau, T. C. \& Wu, M. (2005). Owenweeksia hongkongensis gen. nov., sp. nov., a novel marine bacterium of the phylum 'Bacteroidetes'. Int J Syst Evol Microbiol 55, 1051-1057.

Lau, K. W. K., Ren, J., Wai, N. L. M., Qian, P.-Y., Wong, P.-K. \& Wu, M. (2006). Lishizhenia caseinilytica gen. nov., sp. nov., a marine bacterium of the phylum Bacteroidetes. Int J Syst Evol Microbiol 56, 2317-2322.

Lee, D.-H., Choi, E.-K., Moon, S.-R., Ahn, S., Lee, Y. S., Jung, J. S., Jeon, C. O., Whang, K.-S. \& Kahng, H.-Y. (2010). Wandonia haliotis gen. nov., sp. nov., a marine bacterium of the family Cryomorphaceae, phylum Bacteroidetes. Int J Syst Evol Microbiol 60, 510-514.

Marteinsson, V. T., Bjornsdottir, S. H., Bienvenu, N., Kristjannsson, J. K. \& Birrien, J.-L. (2010). Rhodothermus profundi sp. nov., a thermophilic bacterium isolated from a deep-sea hydrothermal vent in the Pacific Ocean. Int J Syst Evol Microbiol 60, 2729-2734.

Mesbah, M., Premachandran, U. \& Whitman, W. (1989). Precise measurement of the $\mathrm{G}+\mathrm{C}$ content of deoxyribonucleic acid by high performance liquid chromatography. Int J Syst Bacteriol 39, 159-167.
Nedashkovskaya, O. I., Kim, S. B., Han, S. K., Lysenko, A. M., Rohde, M., Rhee, M. S., Frolova, G. M., Falsen, E., Mikhailov, V. V. \& Bae, K. S. (2004). Maribacter gen. nov., a new member of the family Flavobacteriaceae, isolated from marine habitats, containing the species Maribacter sedimenticola sp. nov., Maribacter aquivivus sp. nov., Maribacter orientalis sp. nov. and Maribacter ulvicola sp. nov. Int J Syst Evol Microbiol 54, 1017-1023.

Nedashkovskaya, O. I., Suzuki, M., Lee, J.-S., Lee, K. C., Shevchenko, L. S. \& Mikhailov, V. V. (2009). Pseudozobellia thermophila gen. nov., sp. nov., a bacterium of the family Flavobacteriaceae, isolated from the green alga Ulva fenestrata. Int $\mathrm{J}$ Syst Evol Microbiol 59, 806-810.

Nielsen, P., Fritze, D. \& Priest, F. G. (1995). Phenetic diversity of alkaliphilic Bacillus strains: proposal for nine new species. Microbiology 141, 1745-1761.

Nunes, O. C., Manaia, C. M., da Costa, M. S. \& Santos, H. (1995). Compatible solutes in the thermophilic bacteria Rhodothermus marinus and 'Thermus thermophilus'. Appl Environ Microbiol 61, 2351-2357.

O’Sullivan, L. A., Rinna, J., Humphreys, G., Weightman, A. J. \& Fry, J. C. (2005). Fluviicola taffensis gen. nov., sp. nov., a novel freshwater bacterium of the family Cryomorphaceae in the phylum 'Bacteroidetes'. Int J Syst Evol Microbiol 55, 2189-2194.

Pires, A. L., Albuquerque, L., Tiago, I., Nobre, M. F., Empadinhas, N., Veríssimo, A. \& da Costa, M. S. (2005). Meiothermus timidus sp. nov., a new slightly thermophilic yellow-pigmented species. FEMS Microbiol Lett 245, 39-45.

Rainey, F. A., Ward-Rainey, N., Kroppenstedt, R. M. \& Stackebrandt, E. (1996). The genus Nocardiopsis represents a phylogenetically coherent taxon and a distinct actinomycete lineage: proposal of Nocardiopsaceae fam. nov. Int J Syst Bacteriol 46, 1088-1092.

Silva, Z., Horta, C., da Costa, M. S., Chung, A. P. \& Rainey, F. A. (2000). Polyphasic evidence for the reclassification of Rhodothermus obamensis Sako et al. 1996 as a member of the species Rhodothermus marinus Alfredsson et al. 1988. Int J Syst Evol Microbiol 50, 14571461.

Smibert, R. M. \& Krieg, N. R. (1981). General characterization. In Manual of Methods for General Bacteriology, pp. 409-443. Edited by P. Gerhardt, R. G. E. Murray, R. N. Costilow, E. W. Nester, W. A. Wood, N. R. Krieg \& G. B. Phillips. Washington, DC: American Society for Microbiology.

Sörbo, B. (1987). Sulfate: turbidimetric and nephelometric methods. Methods Enzymol 143, 3-6.

Tenreiro, S., Nobre, M. F., Rainey, F. A., Miguel, C. \& da Costa, M. S. (1997). Thermonema rossianum sp. nov., a new thermophilic and slightly halophilic species from saline hot springs in Naples, Italy. Int $J$ Syst Bacteriol 47, 122-126.

Westley, J. (1987). Thiocyanate and thiosulfate. Methods Enzymol $143,22-25$.

Williams, R. A. \& da Costa, M. S. (1992). The genus Thermus and related microorganisms In The Prokaryotes, 2nd edn, pp. 3745-3753. Edited by A. Balows, H. G. Trüper, M. Dworkin, W. Harder \& K. H. Schleifer. New York: Springer. 